\title{
PERCEPTIONS OF VALUE THAT SUSTAIN COLLABORATIVE NETWORKS
}

\author{
Ronald C. Beckett \\ The Reinvention Network \& University of Wollongong, rcb@reinvent.net.au
}

AUSTRALIA

\begin{abstract}
The author is involved in a multi-year program (called RELINK) to establish a number of large-scale collaboration) projects Potential economic benefits and who may receive them are mapped against three manifestations of a collaboration: a Breeding Environment, a Virtual enterprise, and an Agile Shop Floor. Some Potential participants have concerns that whilst the network may provide them with a vehicle to take on large tasks, but it may also create a new competitor, whilst others are concerned about losing their perceived source of competitive advantage if they start sharing knowledge. Some clients have concerns about large-scale collaborations reducing competyition. So despite a general acceptance of the need to collaborate, the balance between the value obtained and the market positioning of the individual participants needs to be understood.
\end{abstract}

\section{INTRODUCTION}

This paper is written from the perspective of a firm that has been invited to participate in a collaboration. The first question, however expressed, is WIIFM "What's In It For Me". The response is - "an opportunity to more competitively position your business". The questions that follow in regard to specific kinds of benefits, how things will be organized, and how a particular firm may participate lead into the complexities of collaboration. There are different kinds of collaboration with different kinds of participants having differing levels of power and influence. The author is involved in an Australian multi-year program (called RELINK) to establish a number of large-scale (20 - $100 \mathrm{SME}$ manufacturing firms) projects that demonstrate the benefits of collaboration in a real commercial environment. Three demonstration projects are to be centred on actual commercial activity for clients, so that serious buy-in by both clients and participants is necessary. This raises immediate questions by both parties of the value to be delivered by the collaboration.

\section{PREVIOUS STUDIES}

Previous studies by the author $[1,2]$ have identified features valued by the participants that derive from economic, knowledge-sharing and social transactions. Transactions are the lifeblood of collaborations - no transactions, then no effective collaborations. Some housekeeping transactions are required, but whilst these are 
accepted as necessary, they are not perceived to add value. What sustains the collaboration is recurring value adding transactions. Table 1 shows a range of direct economic benefits observed

Table 1 Some Direct Economic Benefits observed in Sustainable Collaborations

\begin{tabular}{|c|c|}
\hline $\begin{array}{c}\text { Type of Economic } \\
\text { Benefit }\end{array}$ & Specific Instance \\
\hline $\begin{array}{l}\text { Revenue } \\
\text { enhancement }\end{array}$ & $\begin{array}{l}\text { - Improved market access via a national brand (eg } \\
\text { www.austmine.com.au) } \\
\text { - Inter-firm trading to meet unique technical or schedule } \\
\text { requirements }\end{array}$ \\
\hline Cost reduction & $\begin{array}{l}\text { - Joint projects focused on internal activities } \\
\text { - Services that access best-of-breed through the network } \\
\text { - Improved purchasing outcomes from buying as a group }\end{array}$ \\
\hline Asset utilization & $\begin{array}{l}\text { - Physical assets - participants acquire complementary } \\
\text { assets rather than duplicate capabilities } \\
\text { - Intellectual assets - participants may share some specialist } \\
\text { staff } \\
\text { - Operating infrastructure - buying some services (eg } \\
\text { design) instead of duplicating them } \\
\text { - Support infrastructure - shared or common software } \\
\text { systems }\end{array}$ \\
\hline Lead time reduction & $\begin{array}{l}\text { - Concurrent engineering practices giving faster turnaround } \\
\text { gives better cash flows } \\
\text { - Supply chain alliances reduce lead time and inventory of } \\
\text { incoming materials }\end{array}$ \\
\hline $\begin{array}{l}\text { Reliability } \\
\text { enhancement }\end{array}$ & $\begin{array}{l}\text { - Quality - collaborative improvement initiatives reduces } \\
\text { scrap and rework } \\
\text { - Schedule consistency supported by redundancy in } \\
\text { resources } \\
\text { - Client communications - single channel customer support } \\
\text { improves consistency, reduces costs }\end{array}$ \\
\hline Risk reduction & $\begin{array}{l}\text { - Financial - higher utilization of new investments } \\
\text { - Reduced dependency on a few key customers } \\
\text { - Shared new market entry costs } \\
\text { - Access to complementary competencies and larger } \\
\text { experience base reduces technical risk } \\
\text { - Inter-region cooperation may support distant customers } \\
\text { better } \\
\text { - Sustain individual firm reputation via improved schedule } \\
\text { performance and broader range of capabilities available }\end{array}$ \\
\hline
\end{tabular}

\section{MAPPING VALUE CREATION OPPORTUNITIES}

Value adding transactions may take place at different stages of the evolution of a sustainable collaboration. Zwegers et al [3] see evolutionary stages as establishing networks from which virtual enterprises are formed to establish projects, which in turn provide goods and services. Previous studies by the author however suggest that 
a collaboration may not get past the network stage. No client projects emerge, but the network stays in operation because the participants are gaining sufficient benefit from inter-firm trading for example. In other cases, some participants only want to be involved for one project, or may be prepared to offer access to some resources, but do not want to participate in network activities. Camarinha-Matos and Afsarmanesh [4] have described a number of manifestations of collaborative networks (see Figure 1), and in the RELINK program three of these: a Breeding Environment, a Virtual enterprise, and an Agile Shop Floor have been used to map benefits observed in past cases studies in each of these manifestations.

\begin{tabular}{|c|c|c|c|c|}
\hline $\begin{array}{l}\text { BREEDING } \\
\text { ENVIRONMENT } \\
\text { Long term } \\
\text { as sociation, } \\
\text { ready to } \\
\text { collab orate }\end{array}$ & $\begin{array}{l}\text { VIRTUAL } \\
\text { ENTERPRISE } \\
\text { Temporary } \\
\text { network, } \\
\text { Goal oriented } \\
\text { consortium }\end{array}$ & $\begin{array}{c}\text { PROFESSIONAL } \\
\text { VIRTUAL } \\
\text { COMMUNITY } \\
\text { Network of } \\
\text { specialist people } \\
\text { Collaborative } \\
\text { spaces }\end{array}$ & $\begin{array}{l}\text { VIRTUAL } \\
\text { LABORATORY } \\
\text { Mixed specialis } \\
\text { \& organisation } \\
\text { network } \\
\text { Specialiised } \\
\text { equipment } \\
\text { access }\end{array}$ & $\begin{array}{c}\text { AGILE } \\
\text { SHOP } \\
\text { FLOOR } \\
\text { Dynamic cells of } \\
\text { manufacturing } \\
\text { resources }\end{array}$ \\
\hline
\end{tabular}

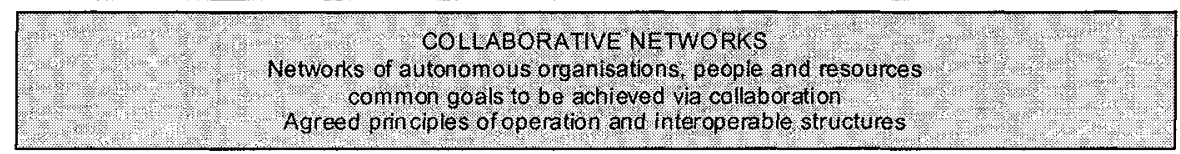

From Camarinha-Matos and Afsarmanesh(2004)

Figure 1 Some observed manifestations of collaborative networks

The other point to be made from these observations is that there is likely to be a heterogeneous mix of actors who may have quite different reasons for participating. These are characterized as:

- Focal firms that have demonstrated project management skills and can muster useful financial resources

- Technology providers that supply tools and methodologies to the participating firms

- Regional networks that may choose to operate outside their region as a single group

- Communities of Practice that operate across firms to identify collective capabilities and facilitate interaction between firms

- Supporting firms that add capacity by providing access to some of their resources on a flexible basis

Our objective is to summarize some likely combinations of these circumstances with potential direct economic benefits to encourage participation in network and virtual enterprise operations. Table 2 gives a summary example of the likely actors and benefits associated with three manifestations of a collaboration. 
Table 2 Some Potential Economic Benefits from Multi-partner Collaboration

\begin{tabular}{|c|c|c|}
\hline MANIFESTATION & TYPICAL ACTORS & $\begin{array}{l}\text { ECONOMIC } \\
\text { OPPORTUNITY }\end{array}$ \\
\hline $\begin{array}{l}\text { BREEDING } \\
\text { ENVIRONMENT }\end{array}$ & $\begin{array}{l}\text { - Focal firms } \\
\text { - Technology Providers } \\
\text { - Regional Networks } \\
\text { - Firms offering } \\
\text { supplementary capacity } \\
\text { - Communities of practice } \\
\text { supporting network } \\
\text { establishment and } \\
\text { operations }\end{array}$ & $\begin{array}{l}\text { - Create Brands } \\
\text { - Expand market access } \\
\text { - Share tangible and } \\
\text { intangible resources to } \\
\text { improve ROI } \\
\text { - Stimulate inter-firm } \\
\text { trading } \\
\text { - Reduce operating costs } \\
\text { - Improve cash flows }\end{array}$ \\
\hline $\begin{array}{l}\text { VIRTUAL } \\
\text { ENTERPRISE }\end{array}$ & $\begin{array}{l}\text { - Client organisation } \\
\text { - Focal firms } \\
\text { - Supplemental firms } \\
\text { - Communities of practice } \\
\text { supporting focal firms }\end{array}$ & $\begin{array}{l}\text { - Undertake client } \\
\text { projects to grow sales } \\
\text { - Undertake participant } \\
\text { cost reduction or } \\
\text { capability building } \\
\text { internal projects }\end{array}$ \\
\hline $\begin{array}{l}\text { AGILE } \\
\text { FLOOR }\end{array}$ & $\begin{array}{l}\text { - Supporting firms } \\
\text { - Communities of Practice } \\
\text { marshalling candidate } \\
\text { firms to access capacity }\end{array}$ & $\begin{array}{l}\text { - Mobilize under-utilized } \\
\text { capacity } \\
\text { - Participate in cost } \\
\text { reduction opportunities }\end{array}$ \\
\hline
\end{tabular}

\section{SOME COMMERCIAL UPSIDES AND DOWNSIDES OF COLLABORATION}

Many of the potential participants are competitors, and some of the larger firms have concerns that whilst the network may provide them with a vehicle to take on large tasks, it may also create a new competitor if some of the small firms get together. The small firms are concerned about losing their perceived source of competitive advantage if they start sharing knowledge with others. Some clients, whilst welcoming the benefits of being able to deal with fewer suppliers, have concerns about large-scale collaborations reducing competition in their supply base.

Biggiero and Sammarra [5] maintain that there are issues of identity and identification. at work too in inter-organisational networks, and this will influence the nature of transactions. They argue that the extent to which the network is seen as a discrete identifiable entity and the extent to which the participants identify with that entity influences the behavior of the participants. This helps to establish boundaries, determines who is in and who is out, and aids in sense-making, all of which improves the efficiency of operation and decision-making. Further Biggiero and Sammarra [5] argue that these factors will influence operational matters differently, depending on the extent of similarity or complementarity in the participants. In networks based on similarity, similar tasks can share common resources to increase efficiency through scale and technical specialisation. We see that housekeeping transactions will mainly relate to task coordination in this case. 
In networks based on complementarity, the participant's tasks are different, but interdependencies help gain reduced coordination costs and increased returns. We see that housekeeping transactions here will mainly relate to interface coordination.

So despite a general acceptance of the need to collaborate, the tradeoff between the value obtained and the market positioning of the individual participants needs to be well understood. Bengtsson and Kock [6] have suggested that simultaneous cooperation and competition between business network participants can be successfully managed if the two aspects are separated and balanced depending on the degree of proximity to the customer and on the competitor's access to specific resources. They suggest that individuals within a firm may only act in one mode (cooperation or competition) at a time. This leads them to suggest that either the two roles are assigned to different individuals within a company, or that one role be controlled and regulated by an intermediate actor such as an industry association (community of practice). In small firms we see that the separation of roles may not be practical, and have observed that they may need to rely on an intermediate actor.

Client perspectives on working with supplier networks seem to be industry sector-specific. The author recently participated in a joint industry - academia workshop including people from the ICT and the Construction Industries. The ICT participants (from Oracle, Cisco and Intel) had titles like Vice-President, Strategic Alliances, reflecting a top-level focus on collaboration, but the impression given was that this consisted of a large number of one-to-one arrangements. Construction Industry participants described a growing enthusiasm for multi-functional team partnering with clients to jointly deal with issues in large, potentially risky infrastructure projects. Agreed target pricing and target schedules were the norm, and these were usually bettered. Frear and Metcalf [7] have reported on the evolution of supplier - customer alliances in the Aerospace Industry, and Boeing have recently rolled out a number of extensive partnership arrangements in the new 787 aircraft development project. An Australian consortium of 3 larger toolmakers, supported by up to sixty others has been formed to bid for work with the tier one aerostructures suppliers on that project. At other conferences however, participants have reported a more adversarial approach to "partnering" in the Automotive Sector. It is speculated that such industry norms may also influence collaboration attitudes right down the supply chain.

\section{DISCUSSION}

In broad terms we see that participants derive value by participating in networking events and by undertaking internal projects or client projects. Whilst the focus is initially on building economic capital, knowledge capital and social capital enhancement also occurs, and this is also valued by some participants. In regard to aspiring participant questions about how things are organised and how they can participate, we have used an activity theory [8,9] framework to characterise some aspects of collaborations aiming to build economic, or knowledge or social capital. The author has found this framework to be a convenient way of comparing activities undertaken in different case study networks [10], and table 3 reflects observations from six recent case studies. It is noted that some commonly used tools are networking events, demonstration projects, celebrations of success, the creation of collective "brands", and ICT tools - a blend of socio-technical components. 
Table 3 Activity Theory frameworks associated with building Economic, Knowledge and Social capital

\begin{tabular}{|c|c|c|c|}
\hline & $\begin{array}{l}\text { BUILDING } \\
\text { ECONOMIC } \\
\text { CAPITAL }\end{array}$ & $\begin{array}{c}\text { BUILDING } \\
\text { KNOWLEDGE } \\
\text { CAPITAL }\end{array}$ & $\begin{array}{l}\text { BUILDING } \\
\text { SOCIAL } \\
\text { CAPITAL }\end{array}$ \\
\hline $\begin{array}{l}\text { OBJECT (The } \\
\text { motivation for } \\
\text { and outcome } \\
\text { sought from the } \\
\text { collaboration) }\end{array}$ & $\begin{array}{l}\text { - Better customer } \\
\text { access to grow } \\
\text { business } \\
\text { - Pursuit of new } \\
\text { cost reduction } \\
\text { opportunities } \\
\text { - Conserve capital }\end{array}$ & $\begin{array}{l}\text { - Market } \\
\text { intelligence } \\
\text { - Technology } \\
\text { intelligence } \\
\text { - Find new } \\
\text { combinations }\end{array}$ & $\begin{array}{l}\text { - Making } \\
\text { Connections } \\
\text { - Building regional } \\
\text { infrastructure and } \\
\text { skill base }\end{array}$ \\
\hline $\begin{array}{l}\text { SUBJECT } \\
\text { (The actors } \\
\text { organising the } \\
\text { activity) }\end{array}$ & $\begin{array}{l}\text {-Typically a lead } \\
\text { group of firms }\end{array}$ & $\begin{array}{l}\text { - Typically a } \\
\text { Community of } \\
\text { Practice }\end{array}$ & $\begin{array}{l}\text { - Typically an } \\
\text { independent } \\
\text { facilitator }\end{array}$ \\
\hline $\begin{array}{l}\text { TOOLS } \\
\text { (Socio-net or } \\
\text { Techno-net } \\
\text { Devices used) }\end{array}$ & $\begin{array}{l}\text { - Brands } \\
\text { - Events } \\
\text { - ICT for data } \\
\text { sharing }\end{array}$ & $\begin{array}{l}\text { - Events } \\
\text { - Demonstration } \\
\text { projects }\end{array}$ & $\begin{array}{l}\text { - Events } \\
\text { - Celebration of } \\
\text { achievements }\end{array}$ \\
\hline $\begin{array}{l}\text { RULES } \\
\text { (Behavioral, } \\
\text { contractual or } \\
\text { competency } \\
\text { based rules for } \\
\text { participation) } \\
\end{array}$ & $\begin{array}{l}\text { - Activities must } \\
\text { make economic } \\
\text { sense } \\
\text { - Client interface } \\
\text { - Trust } \\
\text { - Incentives } \\
\end{array}$ & $\begin{array}{l}\text { - Knowledge } \\
\text { sharing norms } \\
\text { - IP Protection } \\
\text { - Government } \\
\text { incentives }\end{array}$ & $\begin{array}{l}\text { - Ethical behavior } \\
\text { - Participate as a } \\
\text { team member } \\
\text { - Incentives }\end{array}$ \\
\hline $\begin{array}{l}\text { COMMUNITY } \\
\text { (The broader } \\
\text { group of } \\
\text { stakeholders } \\
\text { supporting the } \\
\text { activity) }\end{array}$ & $\begin{array}{l}\text { - Global market } \\
\text { drivers } \\
\text { - Both private and } \\
\text { public } \\
\text { stakeholders }\end{array}$ & $\begin{array}{l}\text { - Technology } \\
\text { providers } \\
\text { - Government } \\
\text { support agencies }\end{array}$ & $\begin{array}{l}\text { - Regional } \\
\text { Governments } \\
\text { - Regional } \\
\text { Associations }\end{array}$ \\
\hline $\begin{array}{l}\text { DIVISION OF } \\
\text { LABOUR } \\
\text { (How some } \\
\text { typical } \\
\text { responsibilities } \\
\text { are assigned) }\end{array}$ & $\begin{array}{l}\text { - Focal firm } \\
\text { leadership } \\
\text { - Technology \& } \\
\text { Capacity support } \\
\text { actors }\end{array}$ & $\begin{array}{l}\text { - Community of } \\
\text { Practice } \\
\text { Leadership } \\
\text { - Government } \\
\text { facilitation } \\
\text { - individual } \\
\text { participant } \\
\text { responsible for } \\
\text { uptake }\end{array}$ & $\begin{array}{l}\text { - Event (place \& } \\
\text { space) } \\
\text { organization } \\
\text { leadership } \\
\text { - Content from } \\
\text { event contributors } \\
\text { - Individual } \\
\text { participant } \\
\text { responsible for } \\
\text { uptake }\end{array}$ \\
\hline
\end{tabular}

We see that these tools also help address identity and identification matters raised by Biggiero and Sammarra [5]. "Incentives" have been noted under the rules category in table 3 . These may relate to imperatives for survival or to government 
intervention strategies, but they often provide an initial stimulus for participation. Earlier in the paper some potential commercial downsides were noted - degradation of competitive position and restriction in client choice. Issues of trust and knowledge sharing were noted in the "rules" row of Table 3. The establishment of appropriate rules / norms can take some time, and this may be inconsistent with the rapid establishment of a collaboration. An approach taken by the author [11] in dealing with these matters is to jointly agree risks to be managed in establishing a collaboration. Discussion of this approach at events, via demonstration projects, at celebrations of success and by sharing information via a website help raise such important issues in an impartial way.

To achieve some knowledge sharing and social capital enhancement outcomes, it is highly likely that some people from the participating organisations will have to meet face-to-face. Consequently, despite the potential power of ICT tools, we see that properly designed (in terms of space, place and content) events that bring people together in an appropriate environment as a primary stimulation process

\section{CONCLUDING REMARKS}

Collaboration needs to make business sense, and a significant list of potential benefits has been presented in this paper. However realizing these potential benefits may be complex. Some firms enter into collaborations to implement company strategies, and are clear from the outset about what they hope to achieve. Others see collaboration as potentially beneficial but also potentially risky, and want a clear statement of benefits in relation to each specific manifestation of a collaboration. Following the formation of a "breeding network", some benefits may accrue from inter-firm trading, or from group purchasing without ever implementing a multipartner client project. Winning significant sized client projects can however provide the greatest potential economic benefits, but the nature of client interaction may be dependent on industry sector norms. The initial focus is on direct economic benefits, but other indirect benefits may emerge - obtaining leverage from knowledge or social capital that might become assessable without ever jointly winning a new client project

Some issues arise in finding an appropriate balance between aspects of similarity and aspects of complementarity between firms. Similar firms tend to be competitors, and unless ways in which they complement each other can be found, having them work together can be difficult. At the same time, finding points of common interest between firms that have different kinds of capabilities is necessary to obtain focus. Both tasks and relationships have to be managed to deliver value

Finally, it is noted that most collaborations aim to service a market need, but the market view of collaborations seem to vary from sector to sector, as whilst the word "collaboration" is commonly used, what it really means may vary from client to client. In the RELINK project [12] referred to earlier in this paper, three different kinds of demonstration projects are planned. One is intended to promote small firms under a national brand, another seeks to combine complementary assets to access a greater depth of skills, and the third one seeks to demonstrate the agile shop floor concept via a virtual enterprise. The characterizations presented in this paper are being used to stimulate the interest of potential participants and to provide a framework for understanding potential roles and outcomes. 


\section{REFERENCES}

1. Beckett, R.C; Hyland, P and Sloan, T (2003) "Mapping Collaborative Transactions in Networks that Yield Business Benefits" Proc $19^{\text {th }}$ Annual IMP Conference, University of Lugano, Switzerland, 4-6 September (ISBN 82-7042-576-1)

2. Beckett, R.C. (2004), "Exploring Sustainable Virtual Enterprises". In "Virtual Enterprises and Collaborative Networks"(Ed L.M. Camarinha-Matos) Kwuhler Academic Publishers, the Netherlands, ISBN 1-4020-8138-3. pp 491-498

3. Zwegers A., Tolle M., Vesterager J., (2003). "Virtual Enterprise Reference Architecture and Methodology", Global Engineering and Manufacturing in Enterprise Networks, VTT Symposium 224, 9-10 December, Helsinki, pp.17-

4. Camarinha-Matos, L.M, and Afsarmanesh, H (2004) "The Emerging Discipline of Collaborative Networks" in "Virtual Enterprises and Collaborative Networks"(Ed L.M. Camarinha-Matos) Kwuhler Academic Publishers, the Netherlands. ISBN 1-4020-8138-3, pp 3-16

5. Biggiero, L. and Sammarra, A., (2001) 'Similarity and complementarity in inter-organisational networks' APROS (Asia-Pacific Researcher in Organisation Studies), Hong Kong Baptist University, 3-5 December

6. Bengstsson, M and Kock, S (2000) "Coopetition in business networks - to cooperate and compete simultaneously. Industrial Marketing Management, Vol 29, Iss 5, p 411

7. Freer, C.R and Metcalf, L.E (1995) "Strategic alliances and technology networks: a study of a castproducts supplier in the aircraft industry" Industrial Marketing Management, Vol 24, Iss 5, p379

8. Vygotsky, L.S. (1978) "Mind and Society" Harvard University Press.

9. Engestrom, Y. (1987) "Learning by expanding: an activity-theoretical approach to developmental research" Helsinki: Orienta-Konsultant

10. Beckett, R.C (2004) "Exploring Virtual Enterprises using Activity Theory". Australian Journal of Information Systems, Vol 12, No 1, pp103-110

11. Beckett, R.C. (2005) "Collaboration now a strategic necessity: Handbook of Business Strategy, Emerald Publishing Group pp $327-332$

12. RELINK (2004) http://relink.agileserve.com 